\title{
Further Study on Maintenance Requirements during Pregnancy in the Rat
}

\author{
Mamoru Saitoh, Seiya Takahashi and Kenichi Kameoka \\ Department of Nutrition, National Institute of Animal Industry, \\ Ibaraki-ken, Kukizaki-mura 305.
}

(Received July 26, 1979)

\begin{abstract}
Nutrient requirements for the maintenance of maternal body during pregnancy of rats were examined. Total 80 of virgin female rats (about $200 \mathrm{~g}$ body weight) of Wistar strain were used for the experiment. It was assumed that ME and DCP requirements for the maintenance corresponded to ME and DCP intakes when both energy and protein retentions were zero. ME requirement $\left(129 \mathrm{kcal} / \mathrm{day} / \mathrm{W}_{\mathrm{kg}}{ }^{0.75}\right)$ for the maintenance of maternal body was similar to that $\left(127 \mathrm{kcal} /\right.$ day $\left./ \mathrm{W}_{\mathrm{kg}} 0.75\right)$ of non-pregnant rats. This fact shows that ME requirement for the maintenance was not affected by pregnancy. On the contrary, DCP requirement $\left(6.91 \mathrm{~g} / \mathrm{day} / \mathrm{W}_{\mathrm{kg}}{ }^{0.75}\right)$ for the maintenance of maternal body was 5 times higher than that $\left(1.30 \mathrm{~g} / \mathrm{day} / \mathrm{W}_{\mathrm{kg}}{ }^{0.75}\right)$ of non-pregnant rats, in spite of positive protein retention. It was considered that DCP requirement for maintenance determined in this experiment includes a part of protein consumed for production (fetus and placenta). Therefore, it is necessary to subtract the amount of protein consumed for production from DCP requirement for maintenance determined in this experiment.

$J p n . J$. Zootech. Sci., 51 (3): 204-214, 1980
\end{abstract}

Nutrient requirements for pregnancy can be estimated by addition of nutrients required for production to maintenance requirements of the maternal body. In our previous experiment ${ }^{11}$, nutrient requirements for maintenance were estimated in the maternal body at late pregnancy (on day 20) and these were compared with those of non-pregnant rats. However, there were two inadequate points in our previous experimental design; first, retentions of both energy and protein were negative in most cases, and secondly, ME and DCP contents of experimental diets were calculated values.

In order to correct the above-mentioned inadequacy, nutrient requirements for maintenance were re-examined under experimental conditions where positive nutrient retention was shown and by the determinations of ME and DCP contents of the experimental dites.

\section{Materials and Methods}

\section{Experimental diets}

To carry out the experiment in the range of positive nutrient retention, different diets were prepared for pregnant and non-pregnant rats, respectively: Twelve diets prepared by combining $4 \mathrm{ME}$ levels $(3.4,4.2,4.7$ and $5.1 \mathrm{kcal} / \mathrm{g}$ in mean values) and 3 DCP levels (23.6, 26.0 and $28.5 \%$ in mean values) for the pregnant rats (Table 1 ), 


\section{Animal experiment}

Virgin female rats (about 10 weeks old) of Wistar strain were used for the experiment. Before the initiation of feeding of experimental diets, these rats were fed once daily about $20 \mathrm{~g}$ of the pelleted diet (Oriental Yeast Kogyo, MF; crude protein $25.3 \%$, crude fat $5.1 \%$, crude ash $7.6 \%$ and moisture $9.8 \%$ ). Drinking water was always available. The temperature was maintained at about $23^{\circ} \mathrm{C}$. Feeding of experimental diets was started on the day (day 0 of pregnancy) when sperm were found in vaginal smears. The rats were reared in individual cages after mating. Body weight on day 0 of pregnancy was about $200 \mathrm{~g}$. In non-pregnant rats, feeding of experimental diets was started on the day when body weight reached about $200 \mathrm{~g}$. Twelve grams of the diet was offered daily to both the pregnant and non-pregnant rats.

These animals were slaughtered under ether anesthesia on day 20 of experiment. Carcass analysis was carried out with the rats which completely consumed the given diet. For the determinations of initial carcass protein and energy contents, four rats (virgin female rats of about $200 \mathrm{~g}$ body weight) were also killed. Uteri and contents of gastro-intestinal tract of these rats were removed prior to the carcass analysis.

\section{Carcass analysis and nutrient retention}

Carcass analysis was conducted by the method described in our previous paper"). Energy or protein retention was determined by subtracting initial carcass energy or protein content from the value on day 20 of experiment. Nutrient retention in pregnant rats was determined in the maternal body from which products of conception (uteri, fetuses, placentae and amniotic fluids) were excluded.

\section{Determination of $D C P$ and $M E$ contents of the experimental diets}

Feces and urine of rats in each dietary group were individually collected using metabolism cages from day 5 to 9 of experiment. DCP content of each diet was obtained from the results of digestion trials with rats using chromic oxide indicator method. $\mathrm{ME}$ contents $\left(\mathrm{ME}_{\mathrm{cnr}}\right.$ ) corrected for nitrogen retention of experimental diets were determined according to the method of HILL and ANDERSON ${ }^{3}$ ) with a modification, replacing 8.22 as the energy for uric acid by 5.43 as that for urea. Thus, the following equation was used.

$M E_{c n r}=E_{\text {diet }}-\left(E_{\text {feces }}+E_{\text {urine }}\right)-5.43 \mathrm{~N}_{\mathrm{r}}$.

where $E_{\text {diet }}=$ gross energy (GE) intake (kcal), $E_{\text {feces }}$ (urine) $=\mathrm{GE}$ in feces (urine) (kcal), $5.43=\mathrm{GE}$ of urea (kcal/g of nitrogen), $\mathrm{N}_{\mathrm{r}}=$ nitrogen retention (g). Energy content in the urine was determined by the method of ITOH and TANO ${ }^{4}$.

Determination of apparent biological values of protein of experimental diets

Apparent biological values (value of $1.32 \mathrm{~g} / \mathrm{kg}$ of dry matter consumed was used as metabolic fecal nitrogen ${ }^{5)}$ ) of protein of the diets were calculated by dividing retained nitrogen by absorbed nitrogen. The values were shown in footnote of Table 3 .

$M E$ and DCP intakes

The data are shown in Table 3. As mentioned above, nutrient retention in pregnant rats was determined with the maternal body from which products of conception were excluded. Therefore, nutrient intakes in pregnant rats were shown as the value 
Maintenance Requirement in Pregnant Rat

Table 3. Daily ME and DCP intakes in pregnant and non-pregnant rats.

\begin{tabular}{|c|c|c|c|c|c|}
\hline \multicolumn{3}{|c|}{ Pregnant } & \multicolumn{3}{|c|}{ Non-pregnant } \\
\hline $\begin{array}{l}\text { Dietary } \\
\text { groups }\end{array}$ & $\begin{array}{c}\mathrm{ME}^{*} \\
\left(\mathrm{kcal} / \mathrm{W}_{\mathrm{kg}}^{0.75}\right)\end{array}$ & $\begin{array}{c}\mathrm{DCP} * * \\
\left(\mathrm{~g} / \mathrm{W}_{\mathrm{kg}}{ }^{0.75}\right)\end{array}$ & $\begin{array}{l}\text { Dietary } \\
\text { groups }\end{array}$ & $\frac{\mathrm{ME}}{\left(\mathrm{kcal} / \mathrm{W}_{\mathrm{kg}}^{0.75}\right)}$ & $\underset{\left(\mathrm{g} / \mathrm{W}_{\mathrm{kg}}^{0.75}\right)}{\operatorname{DCP}}$ \\
\hline 1 & 134 & 6.92 & 13 & 134 & 2.76 \\
\hline 2 & 153 & 6.21 & 14 & 163 & 2.60 \\
\hline 3 & 177 & 6.49 & 15 & 184 & 2.58 \\
\hline 4 & 188 & 7.07 & 16 & 207 & 2.70 \\
\hline 5 & 138 & 7.28 & 17 & 138 & 3.99 \\
\hline 6 & 154 & 7.27 & 18 & 165 & 3.75 \\
\hline 7 & 180 & 8.34 & 19 & 185 & 3.86 \\
\hline 8 & 198 & 8.87 & 20 & 208 & 3.83 \\
\hline 9 & 137 & 7.65 & 21 & 131 & 4.74 \\
\hline 10 & 160 & 9.44 & 22 & 165 & 4.72 \\
\hline 11 & 184 & 8.84 & 23 & 188 & 4.85 \\
\hline 12 & 197 & 9.21 & 24 & 203 & 4.70 \\
\hline
\end{tabular}

*: Corrected ME intake $=\{($ total ME intake $)-($ energy content in products of conception $)\}$. **: Corrected DCP intake $=\{$ (total DCP intake $)-($ protein content in products of conception/apparent biological value of protion of the diet)\}. Apparent biological values (\%) of protein of each diet are as follows: diet 1: 40.7, diet 2:31.9, diet 3: 32.0, diet 4: 34.7, diet 5: 27.9, diet $6: 33.5$, diet 7:36. 2, diet 8: 55.6, diet 9: 21.7, diet 10:41.0, diet 11: 38.9 and diet 12: 41.6. Average protein (g) and energy (kcal) contents in products of conception in each group are as follows: diet 1: 5.30 and 37 , diet 2: 5.05 and 35 , diet $3: 6.04$ and 43 , diet $4: 5.38$ and 40 , diet $5: 5.10$ and 36 , diet $6: 5.47$ and 40, diet 7: 4.51 and 34 , diet $8: 5.79$ and 42 , diet $9: 4.90$ and 35 , diet $10: 4.99$ and 38 , diet 11: 5.25 and 38 , and diet $12: 5.58$ and 34 , respectively.

obtained by subtracting the amounts of nutrients corresponding to energy and protein contents in the products of conception from total ME and DCP intakes, respectively.

$\mathrm{ME}$ intake was corrected on the assumption that dietary ME is completely converted into fetal energy. On the other hand, DCP intake was corrected on the assumption that dietary protein is completely converted to fetal protein when biological value of protein in the diet was $100 \%$.

Nutrient intakes were expressed as the values per metabolic body size ( $\mathrm{Wkg}^{0.75}$ ). on day 0 of experiment.

Relationships between nutrient intakes and nutrient retention

Multiple regression equations between nutrient intakes and nutrient retention were obtained by multiple regression analysis ${ }^{6}$.

Method for the determination of nutrient requirements for maintenance

It was assumed that the maintenance requirements corresponded to ME and DCP intakes when both energy and protein retentions were zero. The method for determining this value was described in our previous paper ${ }^{1}$.

Maintenance requirements were expressed as the values per $\mathrm{Wkg}^{0.75}$ on day 0 of experiment.

Experiment for confirming nutrient requirements for maintenance 
Table 4. Composition of experimental diets for confirming the values of nutrient requirements for maintenance. (in \%)

\begin{tabular}{lcc}
\hline \multicolumn{1}{c}{ Ingredient } & Pregnant & Non-pregnant \\
\hline Casein & 21.5 & 6.0 \\
Corn starch & 52.8 & 66.2 \\
Cellulose powder & 11.0 & 13.1 \\
Soybean oil (+0.02\% BHT) & & 5.0 \\
Glucose & & 5.0 \\
Vitamin mixture & \multicolumn{2}{c}{0.5} \\
Mineral mixture & \multicolumn{2}{|c}{4.0} \\
Choline chloride & \multicolumn{2}{c}{0.1} \\
$\mathrm{Cr}_{2} \mathrm{O}_{3}$ & & 0.1 \\
\hline
\end{tabular}

\begin{tabular}{lcc} 
By analysis: & & \\
$\mathrm{ME}(\mathrm{kcal} / \mathrm{g})^{*}$ & 3.3 & 3.2 \\
$\mathrm{DCP}(\%)$ & 17.2 & 3.3 \\
\hline $\mathrm{ME}$ and DCP intakes: & & \\
$\mathrm{dME}\left(\mathrm{kcal} / \mathrm{day} / \mathrm{W}_{\mathrm{kg}}{ }^{0.75}\right)$ & 133 & 129 \\
$\mathrm{DCP}\left(\mathrm{g} / \mathrm{day} / \mathrm{W}_{\mathrm{kg}}{ }^{0.75}\right)$ & 7.01 & 1.33 \\
\hline
\end{tabular}

*: ME corrected for nitrogen retention.

The experiment was conducted to confirm an assumption that both carcass energy and protein retentions become zero when the diet meeting $\mathrm{ME}$ and DCP requirements for maintenance is given.

Experimental diets are shown in Table 4. Daily ME and DCP intakes per $\mathrm{W}_{\mathrm{kg}^{0.75}}$ in the two dietary groups designed for confirming nutrient requirements for maintenance were approximately equal to the values of minimum maintenance requirements. Feeding condition and the method for carcass analysis were as described above.

\section{Results}

Nutrient retention in the maternal body and non-pregnant rats

In the maternal body, protein retention showed positive values in all the dietary groups, while energy retention was negative in 3 out of 12 dietary groups (Tables 5 and 6). In non-pregnant rats, similarly, positive values were obtained for protein retention in all the dietary groups, whereas energy retention showed negative values in 2 out of 12 dietary groups.

Multiple regression equations between nutrient intakes and nutrient retention were led from Tables 5 and 6.

$$
\begin{aligned}
& Y_{p p}=-13.05+1.145 X_{1}-0.02704 X_{1}{ }^{2}+0.09648 X_{2}-0.0001173 X_{2}{ }^{2}-0.004573 X_{1} X_{2} \cdots \cdots \cdots(1) t \\
& \qquad \begin{array}{l}
\left(\mathrm{R}=0.911, \mathrm{P}<0.01 ; \mathrm{R}^{2}=83.0 \%\right) \\
\text { where } \\
\quad Y_{p p}=\text { protein retention in the maternal body }\left(\mathrm{g} / \mathrm{day} / \mathrm{W}_{\mathrm{kg}}{ }^{0.75}\right) . \\
X_{1}=\text { corrected } \mathrm{DCP} \text { intake by pregnant rats }\left(\mathrm{g} / \text { day } / \mathrm{W}_{\mathrm{kg}}{ }^{0.75}\right) . \\
X_{2}=\text { corrected } \mathrm{ME} \text { intake by pregnant rats }\left(\mathrm{kcal} / \mathrm{day} / \mathrm{W}_{\mathrm{kg}}{ }^{0.75}\right) .
\end{array}
\end{aligned}
$$


Maintenance Requirement in Pregnant Rat

Table 5. Protein and energy retentions in the maternal body.

\begin{tabular}{cccc}
\hline \multirow{2}{*}{$\begin{array}{c}\text { Dietary } \\
\text { groups }\end{array}$} & $\begin{array}{c}\text { No. of } \\
\text { rats }\end{array}$ & \multicolumn{2}{c}{ Retention* $^{*}$} \\
\cline { 3 - 4 } & & $\begin{array}{c}\text { protein } \\
\text { energy }\end{array}$ \\
\hline 1 & 4 & $0.09 \pm 0.04^{* *}$ & $-21.2 \pm 1.7^{* *}$ \\
2 & 3 & $0.83 \pm 0.16$ & $13.7 \pm 3.1$ \\
3 & 3 & $1.22 \pm 0.10$ & $24.6 \pm 1.8$ \\
4 & 4 & $1.69 \pm 0.14$ & $32.0 \pm 2.9$ \\
5 & 3 & $0.15 \pm 0.07$ & $-20.9 \pm 0.8$ \\
6 & 4 & $0.92 \pm 0.10$ & $9.2 \pm 1.7$ \\
7 & 3 & $1.23 \pm 0.13$ & $19.4 \pm 0.5$ \\
8 & 4 & $1.52 \pm 0.16$ & $37.7 \pm 1.9$ \\
9 & 4 & $0.49 \pm 0.07$ & $-13.8 \pm 2.0$ \\
10 & 4 & $0.89 \pm 0.06$ & $14.9 \pm 2.3$ \\
11 & 4 & $1.24 \pm 0.03$ & $24.6 \pm 1.9$ \\
12 & 4 & $1.37 \pm 0.21$ & $38.1 \pm 2.9$
\end{tabular}

$W_{\mathrm{kg}}{ }^{0.75}$ denotes metabolic body size on day 0 of pregnancy. **: Mean \pm S. E.

Table 6. Protein and energy retentions in non-pregnant rat.

\begin{tabular}{ccc}
\hline \multirow{2}{*}{$\begin{array}{c}\text { Dietary } \\
\text { groups }\end{array}$} & \multicolumn{2}{c}{ Retention* } \\
\cline { 2 - 3 } & protein & energy \\
\hline 13 & $\left(\mathrm{~g} /\right.$ day $\left./ \mathrm{W}_{\mathrm{kg}} \mathbf{0 . 7 5}^{*}\right)$ & $\left(\mathrm{kcal} /\right.$ day $\left./ \mathrm{W}_{\mathbf{k g}}{ }^{0.75}\right)$ \\
14 & $0.59 \pm 0.09^{* *}$ & $-12.4 \pm 1.0^{* *}$ \\
15 & $0.80 \pm 0.12$ & $19.4 \pm 1.0$ \\
16 & $1.16 \pm 0.07$ & $23.6 \pm 1.3$ \\
17 & $0.66 \pm 0.06$ & $-11.5 \pm 2.7$ \\
18 & $1.24 \pm 0.05$ & $21.8 \pm 0.8$ \\
19 & $0.94 \pm 0.03$ & $21.0 \pm 1.0$ \\
20 & $1.46 \pm 0.05$ & $19.9 \pm 0.9$ \\
21 & $0.27 \pm 0.16$ & $7.4 \pm 1.3$ \\
22 & $0.90 \pm 0.14$ & $18.3 \pm 0.3$ \\
23 & $1.30 \pm 0.08$ & $22.2 \pm 1.5$ \\
24 & $1.24 \pm 0.13$ & $37.8 \pm 0.6$
\end{tabular}

*: $W_{\mathrm{kg}} \mathrm{0}^{.75}$ denotes metabolic body size on day 0 of experiment.

**: Mean \pm S. E. for 3 rats.

$Y_{\phi e}=31.89-90.22 X_{1}+4.864 X_{1}^{2}+4.055 X_{2}-0.008937 X_{2}^{2}-0.01738 X_{1} X_{2}$

$$
\left(\mathrm{R}=0.973, \mathrm{P}<0.01 ; \mathrm{R}^{2}=94.7 \%\right)
$$

where

$Y_{p e}=$ energy retention in the maternal body $\left(\mathrm{kcal} /\right.$ day $\left./ \mathrm{W}_{\mathbf{k g}}{ }^{0.76}\right)$.

$X_{1}=$ corrected DCP intake by pregnant rats $\left(\mathrm{g} /\right.$ day $\left./ \mathrm{W}_{\mathrm{kg}}{ }^{0.75}\right)$.

$X_{2}=$ corrected ME intake by pregnant rats $\left(\mathrm{kcal} / \mathrm{day} / \mathrm{W}_{\mathrm{kg}}{ }^{0.75}\right)$. 
$Y_{n p}=-2.656+0.4778 X_{1}-0.1315 X_{1}^{2}+0.02266 X_{2}-0.0000696 X_{2}^{2}+0.003063 X_{1} X_{2}$

$\left(\mathrm{R}=0.861, \mathrm{P}<0.01 ; \mathrm{R}^{2}=74.2 \%\right)$

where

$Y_{n p}=$ protein retention in non-pregnant rats $\left(\mathrm{g} / \mathrm{day} / \mathrm{W}_{\mathrm{kg}}{ }^{0.75}\right)$.

$X_{1}=$ DCP intake by non-pregnant rats $\left(\mathrm{g} /\right.$ day $\left./ \mathrm{W} \mathrm{kg}^{0.75}\right)$.

$X_{2}=\mathrm{ME}$ intake by non-pregnant rats $\left(\mathrm{kcal} / \mathrm{day} / \mathrm{W}_{\mathrm{kg}}{ }^{0.75}\right)$. $Y_{n \varepsilon}=-237.5-21.89 X_{1}+6.199 X_{1}{ }^{2}+2.918 X_{2}-0.005812 X_{2}{ }^{2}-0.1265 X_{1} X_{2}$

$\left(\mathrm{R}=0.916, \mathrm{P}<0.01 ; \mathrm{R}^{2}=83.9 \%\right)$

where

$Y_{n e}=$ energy retention in non-pregnant rats $\left(\mathrm{kcal} / \mathrm{day} / \mathrm{W}_{\mathrm{kg}^{0.75}}\right)$.

$X_{1}=$ DCP intake by non-pregnant rats $\left(\mathrm{g} /\right.$ day $\left./ \mathrm{W}_{\mathrm{kg}}{ }^{0.75}\right)$.

$X_{2}=\mathrm{ME}$ intake by non-pregnant rats $\left(\mathrm{kcal} / \mathrm{day} / \mathrm{W}_{\mathrm{kg}}{ }^{0.75}\right)$.

Multiple correlation coefficients $(R)$ and percentage variation explained by $R$ square $\left(R^{2}\right)$ in these equations were very high. Accordingly, it is considered that the relationships between nutrient intakes and nutrient retention are well explained by these regression equations.

Minimum DCP and ME requirements for maintenance of the maternal body and for non-pregnant rats

As shown in Figures 1 and 2, the curves of zero energy retention and zero protein retention intersected at 2 points in both pregnant and non-pregnant rats. In Fig-

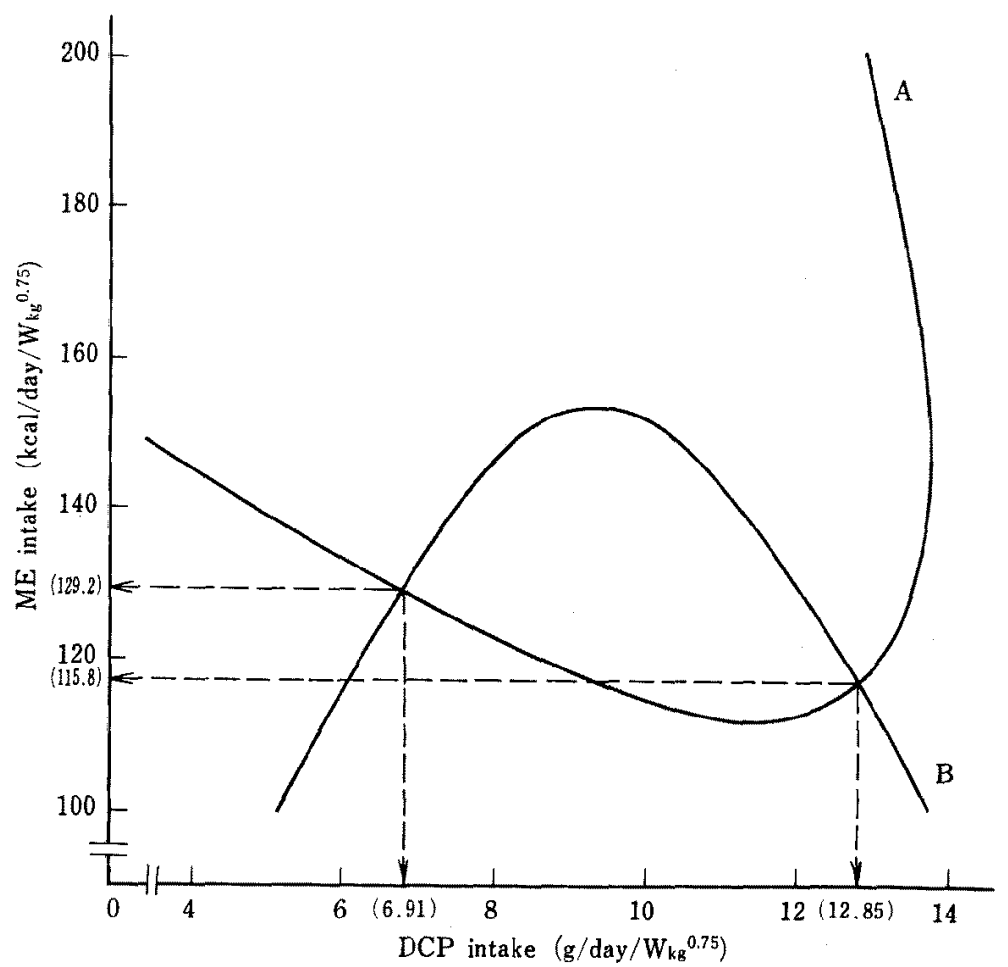

Fig. 1. Determination of DCP and ME requirements for maintenance in the maternal body. Curves $A$ and $B$ denote the curves of 0 protein and 0 energy retention, respectively. 


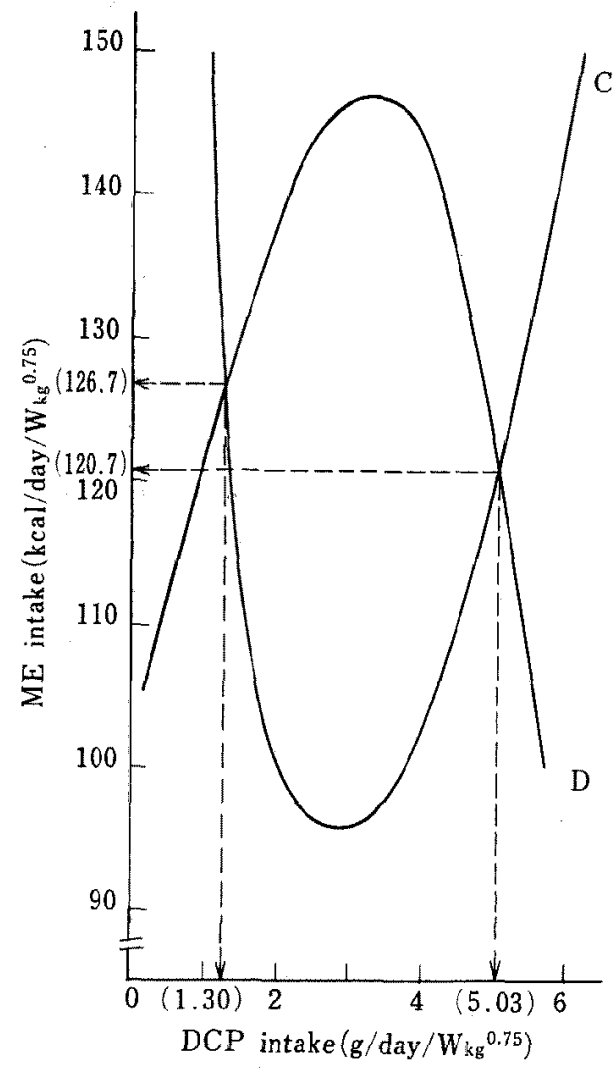

Fig. 2. Determination of $\mathrm{DCP}$ and $\mathrm{ME}$ requirements for maintenance in non-pregnant rat. Curves $C$ and $D$ denote the curves of 0 protein and 0 energy retention, respectively.

ures 1 and 2, it was shown that ME intakes corresponding to the intersecting points of the two curves did not differ so much whereas considerable differences were found in DCP intakes for the intersecting points. Therefore, the authors selected the points corresponding to the smaller values for DCP intake as ME and DCP requirements and showed them in Table 7.

Table 7 indicates that $\mathrm{ME}$ requirement for maintenance in the maternal body was similar to that of non-pregnant rats, while DCP requirement for maintenance in the maternal body was about 5 times greater than that of non-pregnant rats.

Table 7. Minimum ME and DCP requirements for maintenance in the maternal body and non-pregnant rat.

\begin{tabular}{|c|c|c|c|c|c|}
\hline \multicolumn{2}{|c|}{ Maternal body (M) } & \multicolumn{2}{|c|}{ Non-pregnant $(\mathrm{N})$} & \multicolumn{2}{|c|}{$\mathrm{M} / \mathrm{N}$ ratio } \\
\hline $\mathrm{ME}^{*}$ & DCP** & $\mathrm{ME}^{*}$ & DCP** & $\mathrm{ME}$ & DCP \\
\hline 129 & 6.91 & 127 & 1.30 & 1.02 & 5.32 \\
\hline
\end{tabular}

*: $\mathrm{kcal} / \mathrm{day} / \mathrm{W}_{\mathrm{kg}}{ }^{0.75}$. **: $\mathrm{g} / \mathrm{day} / \mathrm{W}_{\mathrm{kg}}{ }^{0.75}$. 
Table 8. Energy and protein retentions in pregnant and non-pregnant rats given the diets having nutritive value approximately equal to minimum $\mathrm{ME}$ and $\mathrm{DCP}$ requirements for maintenance.

\begin{tabular}{ccc}
\hline Item & Maternal body & Non-pregnant \\
\hline Energy & $2.8 \pm 0.5^{*}$ & $2.6 \pm 0.5^{*}$ \\
$\left(\mathrm{kcal} / \mathrm{day} / \mathrm{W}_{\mathrm{kg}}{ }^{0.75}\right)$ & $(4)^{* *}$ & $(3)^{* *}$ \\
Protein & $0.24 \pm 0.06$ & $0.11 \pm 0.05$ \\
$\left(\mathrm{~g} /\right.$ day $\left./ \mathrm{W}_{\mathrm{kg}}{ }^{0.75}\right)$ & $(4)$ & $(3)$ \\
\hline
\end{tabular}

*: Mean \pm S.E. **: Figures in parentheses indicate the numbers of rats used for carcass analysis.

Results of experiment for confirming $M E$ and DCP requirements for maintenance The results are shown in Table 8. The mean values of energy and protein retentions in pregnant and non-pregnant rats given the diets having nutritive value approximately equal to minimum $\mathrm{ME}$ and $\mathrm{DCP}$ requirements for maintenance were somewhat higher than zero.

\section{Discussion}

This experiment showed that minimum $M E$ requirement for maintenance in the maternal body was similar to that of non-pregnant rats. This tendency is in agreement with the result of our previous experiment ${ }^{1}$. Quite recently, LODGE et al. ${ }^{37}$ have reported that $\mathrm{ME}$ requirement for maintenance per $\mathrm{W}_{\mathrm{kg}}{ }^{0.75}$ per day is estimated to be $108 \mathrm{kcal}$ for both pregnant and non-pregnant gilts in summer, and $158 \mathrm{kcal}$ and 153 kcal for pregnant and non-pregnant gilts, respectively, in winter. From these results, they have concluded that pregnancy has little or no influence on ME requirement for maintenance.

Minimum ME requirement for maintenance in non-pregnant rats obtained in this experiment was about $20 \%$ higher than the value $\left(106 \mathrm{kcal} / \mathrm{day} / \mathrm{W}_{\mathrm{kg}}{ }^{0.75}\right)$ reported in rats $^{8}$. This may be due to the differences of the age and body weight of rats used, composition of experimental diet and room temperature ${ }^{\text {s). }}$

It was also indicated that minimum DCP requirement for maintenance of the maternal body was about 5 times higher than that of non-pregnant rats even under experimental conditions where positive protein retention is shown. This tendency is also in agreement with the result of our previous experiment ${ }^{12}$.

In our previous experiment ${ }^{10)}$, it was observed that protein retention in the maternal body reached peak value on day 17 of pregnancy and then decreased toward late pregnancy. It was considered that this decrease was due to the transfer of protein from the maternal body to fetus. The phenomenon was also observed under ad libitum feeding of the diet containing enough nutrients (SAIтOH, M., et al., unpublished data. 1979). Judging from these facts, it is possible that DCP requirement for maintenance determined in this experiment includes a part of requirement for production due to the transfer of protein from the maternal body to fetus and the loss of protein in conversion from protein of the maternal body to fetal protein. Consequent- 
ly, it is necessary to subtract the amount of protein consumed for production from DCP requirement for maintenance determined in this experiment.

Minimum DCP requirement for maintenance $\left(1.30 \mathrm{~g} /\right.$ day $\left./ \mathrm{W} \mathrm{kg}^{0.75}\right)$ in non-pregnant rats obtained in this experiment was in good agreement with the mean value of data calculated from the literatures $\left(1.25 \mathrm{~g} / \mathrm{day} / \mathrm{Wkg} \mathrm{g}^{0.75}\right)^{8)}$.

An experiment was conducted in this study to confirm the assumption that both energy and protein retentions become actually zero in rats given the diet equal to $\mathrm{ME}$ and DCP requirements for maintenance determined by mathematical method as mentioned above. Protein and energy retentions in these rats were somewhat higher than zero. This difference may be due to the facts that DCP and ME intakes in the experiment shown in Table 4 are set up 2.3\% higher in DCP and 1.6\% higher in ME in non-pregnant rats, and $1.4 \%$ higher in DCP and $3.1 \%$ higher in pregnant rats compared with minimum DCP and ME requirements for maintenance in non-pregnant and pregnant rats shown in Table 7. From these facts, it is considered that both protein and energy retentions in rats given the diets approximately equal to minimum DCP and ME requirements for maintenance are nearly zero. Therefore, the result demonstrates that no large error exists in the method employed for determining maintenance requirements in this experiment.

In respect of conversion efficiencies from dietary DCP and ME to fetal protein and energy, it was assumed in this study that dietary DCP completely converted to fetal protein when biological value of protein of the diet was $100 \%$ and $\mathrm{ME}$ of the diet completely converted to fetal energy. It has been reported that conversion efficiency from dietary $\mathrm{ME}$ to fetal energy is 10 to $25 \%$ in ruminants ${ }^{11}$. Further studies are necessary in order to clarify the efficiency of conversion from dietary energy to fetal energy.

The authors thank Dr. Yoshinobu OHyama for his valuable comments on the manuscript and his help with the English language. The authors are also indebted to Mr. Mikio Ando for statistical analyses of the data, Mrs. Fusako Usur and Mrs. Etsuko Yозніока for care of the animals and chemical analyses of the samples.

\section{References}

1) Saitoh, M., S. Takahashi and K. Kamzoka, Jpn. J. Zootech. Sci., 50: 411-418. 1979.

2) SaITOH, M. and S. Takahashi, J. Nutr, 103: 1652-1657. 1973.

3) Hill, F. W. and D. L. Anderson, J. Nutr., 64: 587-603. 1959.

4) Iтон, M. and R. Tano, Bull. Nat. Inst. Anim. Ind., 32: 39-43. 1977.

5) Kawabata, K., Bulletin of the Computing Centre for Research in Agriculture, Forestry and Fishery. Series A. No. 8. 65-133. 1972.

6) Lodge, G. A., D. W. Friend and M.S. Wolynetz, Can. J. Anim. Sci., 59: 51-61. 1979.

7) National Academy of Science-National Research Council. Nutrient Requirements of Domestic Animals. No. 10. Nutrient Requirements of Laboratory Animals. 3rd rev. ed. 7-37. 1978.

8) Van Es, A. J. H., Maintenance. in Handbuch der Tierernährung. 2, Leistungen und Ernährung (Lenkert, W. and K. Breirem, eds.) 1-54. Verlag Paul Parey. Hamburg und Berlin. 1972.

9) Sartoh, M. and S. Takahashi, Jpn. J. Zootech. Sci., 51: 112-119. 1980.

10) Moe, P. W. and H.F. Tyrrell, J. Anim. Sci., 37: 183-189. 1973. 


\title{
妊娠期におけるラットの維持養分量に関する再榆討
}

\author{
斎藤守・高橋正也・重岡暄一 \\ 農林水産省畜産試験場，茨城県茎崎村 305
}

\begin{abstract}
本实験においては，妅娠期における母体の維持比要す る $\mathrm{ME}$ 抢よび DCP 量について，ラット学用いて検討 し，あすせて非娃娠ラットに㧍けるそれらとの比較を行 なった，供試飼料は，娃娠および非娃娠用として，それ ぞれ 12 䧽類（ME 4 水隻と DCP 3 水準の組合せ）の飼 料を用小大。供試動物は，ウィスター系雌ラット（体重 約 $200 \mathrm{~g}$ の未経産) 80 匹供試した. ここでの維持に要 する $\mathrm{ME}$ および $\mathrm{DCP}$ 量とは，エネルギーおよび蛋白質 蓄䆅量が，ともに0になる時点の ME 打よび DCP 提 取量相当分とした，关の結果，母体の維持に要する $\mathrm{ME}$
\end{abstract}

量は，非奸娠ラットの埸合とほほ等しく，それぞれ 129 と $127 \mathrm{kcal} / \mathrm{day} / \mathrm{W}_{\mathrm{kg}} \mathbf{0}^{0.75}$ であった。一方，因体の維持に 要する DCP 量は，蛋白質の蓄樻量を正の領域で求めた にもかかわらず，非妊娠ラットの場合に比べて約 5 倍む 高く，それぞれ 6.91 と $1.30 \mathrm{~g} / \mathrm{day} / \mathrm{W}_{\mathrm{kg}} 0.75$ となった。 なお，妊娠末期の維持に要する DCP 量には，胎児や胎 盤などの生産のために消費された㔻白質を含む可能性が 推測されたので，本实験で算定した維持の蛋白貿量加 ら，生産化使われた分学控除することが，今俊必要であ る. 日畜会報; $51(3) ： 204-214,1980$ 